\title{
Backfat and carcass composition of piglets fed milk replacers containing vegetable oil compared with sow-reared piglets
}

\author{
ER Farnworth 1, MS Wolynetz 2, HW Modler 1, \\ JKG Kramer 1, FD Sauer 1, KM Johnston 3 \\ 1 Centre for Food and Animal Research; \\ 2 Research Program Service; \\ ${ }^{3}$ Animal Disease Research Institute, Agriculture Canada, Ottawa, K1A0C6 Canada
}

(Received 26 May 1993; accepted 19 October 1993)

\begin{abstract}
Summary - The carcass composition of piglets fed artificial milk was compared to sow-reared piglets. The artificial milk diets contained $25 \%$, by weight, soybean oil or mixtures of canola and high erucic acid rapeseed oil. Both the total lipid and nitrogen (apparent) digestibility of the artificial milk diets was high, even when the dietary oil contained high levels of erucic acid. Sow-reared animals were matched with the piglets receiving the artificial milk by sex and live body weight. On both a relative and an absolute basis, the piglets receiving the artificial milk diets had less carcass fat than sowreared animals. The per cent nitrogen and ash of the carcasses of sow-reared piglets were significantly reduced compared with piglets eating milk replacer. The fatty-acid patterns of the backfat of the piglets generally resembled the patterns of the dietary lipids. Piglets eating vegetable oil diets had long-chain polyunsaturated fatty acids in their backfat, even though the oils they were consuming did not.
\end{abstract}

carcass composition / piglet / milk replacer / vegetable oil

Résumé - Composition corporelle du porcelet sevré artificiellement. La composition des carcasses de porcelets ayant reçu un lait antificiel a été comparée à celle de porcelets élevés sous la mère. Les régimes au lait artificiel contenaient, en poids, $25 \%$ d'huile de soja ou de mélanges $d^{\prime}$ huiles de colza riches ou pauvres en acide érucique. La digestibilité apparente des lipides totaux et de l'azote des régimes artificiels était forte, même quand l'huile était riche en acide érucique. Les porcelets élevés sous la mère ont été appariés en poids vif et sexe avec ceux recevant le lait artificiel. $\dot{A}$ la fois sur une base absolue et relative, les porcelets nourris au lait artificiel étaient moins gras que les porcelets allaités. Les pourcentages d'azote et de cendres des carcasses des porcelets nourris sous la mère étaient significativement réduits comparativement aux porcelets recevant le lait de remplacement. Les profils des acides gras du gras dorsal des porcelets étaient en général voisins de ceux des lipides alimentaires. Les porcelets consommant les régimes à huiles végétales avaient des acides gras polyinsaturés à longue chaîne dans leur gras dorsal, bien que les huiles alimentaires n'en contenaient pas. 


\section{INTRODUCTION}

Sows' milk contains approximately $40 \%$ fat on a dry matter basis. Generally, sows' milk is high in saturated fatty acids, the monounsaturated oleic acid, and contains significant amounts of $\mathrm{C}_{20}$ and $\mathrm{C}_{22}$ polyunsaturated fatty acids (PUFAs). The fat in sows' milk fat is highly digestible and the pattern of fatty acids in the milk appears in the backfat of the piglet soon after suckling begins (Miller et al, 1971; Stahly et al, 1981).

The growth of the sow-reared piglet is dependent on an adequate supply of milk. Variables such as order of birth, weight at birth and size of litter can influence the supply of milk an individual piglet receives. This can result in large variations in piglet growth and, presumably, body composition.

Methods of artificially rearing pigs did not initially enjoy wide acceptance because of poor survival and performance records, and the need for a near sterile environment (Lecce, 1975, 1986). The addition of immunoglobulins to pig milk replacers has overcome many of these problems (Elliot et al, 1978, 1987). An artificial rearing system has the advantage of being able to control the amount of milk an individual piglet receives, and through selection of different ingredients the amount and composition of a particular nutrient, eg, fat, can be changed. It might be possible, then, to control the growth and body composition of a piglet by feeding it a milk replacer.

The composition of pig milk replacer can easily be modified. The fat levels of milk replacers are lower than sows' milk, and if vegetable oils are used, the fattyacid pattern in the milk replacer differs from that in sows' milk. The vegetable oils are more unsaturated than the lipids of sows' milk, and they do not contain $\mathrm{C}_{20}$ and $\mathrm{C}_{22}$ PUFAs. It is not known how these differences between sows' milk and milk replacer will affect the piglet.

The purpose of this study was to determine the effects of using different vegetable oils as the main source of lipid in piglet milk replacer on the body composition of piglets reared on milk replacer. This was done by comparing proximate analyses data from sow-reared piglets to artificially reared piglets. In addition, backfat fatty acid analyses were done to measure the deposition of various fatty acids in the diet by the neonatal pig. The essential fatty acids, linoleic acid (18:2n-6) and linolenic acid $(18: 3 n-3)$, were measured as were the long-chain PUFAs. Erucic acid $(22: 1 n-9)$ was also studied to determine whether the neonatal pig utilized this fatty acid. If it did, it would mean that the pig was a better animal model for investigating the effects of erucic acid in humans than the rat, since the absorption and metabolism of erucic acid by the rat is poor (Sauer and Kramer, 1983).

\section{MATERIALS AND METHODS}

\section{Milk replacer diets}

Milk replacer was produced at our processing facilities; its preparation and composition have been described previously (Farnworth et al, 1990). Each milk replacer contained $25 \%$ by weight vegetable oil (see table I). High erucic $(43 \% 22: 1 n-9)$ acid rapeseed (HEAR) oil was used alone or mixed with canola oil $10.8 \%$ $22: 1 n-9)$ to produce oil mixtures containing approximately $2,7,12,20$ or $43 \%$ erucic acid $(22: 1 n-9)$. A diet containing soybean oil was also used. The fatty acid compositions of the oils used in the milk replacers are given in table II. The milk replacer was combined with a colostrum substitute, rich in immunoglobulins (Elliot et al, 1987) and was reconstituted with water in the swine barn daily. 


\section{Animals, feeding and housing}

Piglets were obtained from sows in our minimum disease herd. Only piglets from litters that contained at least 8 pigs with a body weight of greater than $900 \mathrm{~g}$ at birth were used. Piglets selected to receive the milk replacer diets were left with their dam for 24-36 h. They were then transferred to a separate room that had been fumigated ( $d 0$ of experiment). Piglets were housed individually in stainless-steel cages fitted with an automated liquid feeding system (Reid et al, 1979). The liquid milk was fed at 2-h intervals over a $24-h$ period. Piglets were weighed every $3 \mathrm{~d}$ and the feeding level of each individual pig adjusted to a dry matter intake equal to $7 \%$ of body weight (to prevent overeating). A total of 66 pigs (11 groups of 6 ) were fed milk replacer; 2 groups received the diet containing soybean oil; 2 groups the $2 \%$ erucic acid diet; 3 groups the $7 \%$ erucic acid diet; 2

Table I. Milk replacer formula: dry matter constituents a.

\section{Ingredients}

$\%$

$\begin{array}{lc}\text { Gamma globulin supplemented } & \\ \text { skim milk powder } \mathrm{b} & 16.0 \\ \text { Low temperature skim milk powder } & 50.33 \\ \text { Casein } & 5.0 \\ \text { D, L-Methionine } & 0.3 \\ \text { Test oil } & 25.0 \\ \text { Vitamin premix c } & 1.00 \\ \text { Trace mineral premix d } & 1.00 \\ \text { Calcium chloride (36.1\% Ca) } & 0.17 \\ \text { Soy lecithin } & 1.125 \\ \text { Tween-80 } & 0.075 \\ \text { Total } & 100.000\end{array}$

a Dry matter constituents to be mixed with water to produce a diet containing $21 \%$ solids; ${ }^{b}$ source of gamma globulin is from porcine blood; ${ }^{c}$ provides per $\mathrm{kg}$ of milk replacer: vitamin A, $5720 \mathrm{lU}$; vitamin D, $520 \mathrm{IU}$; vitamin $\mathrm{E}, 25 \mathrm{IU}$; vitamin $\mathrm{K}_{1}, 4.84 \mathrm{mg}$; thiamin, $3.19 \mathrm{mg}$; biotin, $280 \mu \mathrm{g}$; riboflavin, $6.6 \mathrm{mg}$; niacin, $48.4 \mathrm{mg}$; calcium pantothenate, $62.7 \mathrm{mg}$; pyridoxine, $4.0 \mathrm{mg}$; vitamin $B_{12}$, $48.4 \mu \mathrm{g}$; choline chloride, $3.21 \mathrm{~g}$; ${ }^{d}$ provides per $\mathrm{kg}$ of milk replacer: $125 \mathrm{ppm} \mathrm{Fe;} 10 \mathrm{ppm} \mathrm{Cu} ; 20 \mathrm{ppm} \mathrm{Mn;}$ 100 ppm Zn; 0.2 ppm I $;$ and 0.3 ppm Se. groups the $12 \%$ erucic acid diet; 1 group the $20 \%$ erucic acid diet and 1 group the HEAR (42.9\% erucic acid) oil diet.

To obtain sow-reared comparison groups, piglets were chosen from conventionally reared litters. The sow-reared control groups contained 1 piglet chosen to match an artificially reared piglet in both sex and live body weight at time of slaughter. Male piglets were not castrated. The age of the sow-reared piglets was recorded when they were taken from the sow. Sows had received a standard gestation diet (corn, 43\%; barley, $35 \%$; soybean meal, $9 \%$; bran, $5 \%$ ) and lactation diet (corn, $49.9 \%$; barley, $25.0 \%$; soybean meal, $17 \%$ ), and had water in the farrowing crate ad libitum. The fatty acid profile and lipid content of sows' colostrum and milk are given in table II.

\section{Milk replacer digestibility determination}

Fecal collections were made from piglets in 10 of the 11 groups (6 piglets/group) fed the various milk replacers (one $7 \%$ erucic group omitted). The samples for individual pigs were pooled every $3 \mathrm{~d}$, and dry matter, total fat (acidification followed by ether extraction), and nitrogen (Kjeldahl method) were determined when sufficient sample was available. Apparent digestibility of nitrogen and total lipid were calculated from composition analyses of the diet, daily milk replacer intake values and the fecal compositional data.

\section{Carcass analysis}

Piglets were killed after eating the milk replacer $6,9,12$ or 15 d by exsanguination after anesthesia. Carcasses were frozen until further processing. Samples (random subset, minimum of 6 pigs per diet group) of backfat were removed from 3 locations along the back (the mid-line at the shoulder, mid-back, rump), extracted with chloroform/methanol (2:1, vol/vol) (Christie, 1982) and fatty acids determined by gas chromatography (Kramer et al, 1985). The whole carcass, including the head but not including the internal organs, was then processed using the autoclave method (Patience and Farnworth, 1989). Total body fat (determined as the chloro- 
Table II. Fatty-acid composition of sows' colostrum and milk and dietary oils.

Fatty acids Sows'colostruma Sows'milka Soybean oil Canola oil HEAR oil

\begin{tabular}{|c|c|c|c|c|c|}
\hline & & & (area \%) & & \\
\hline$\leq 14: 0$ & 1.6 & 2.1 & 0.1 & 0.1 & 0.1 \\
\hline $16: 0$ & 22.7 & 23.3 & 9.9 & 5.2 & 3.2 \\
\hline $16: 1$ & 4.1 & 4.6 & 0.2 & 0.3 & 0.2 \\
\hline $18: 0$ & 5.7 & 6.1 & 3.6 & 2.2 & 1.2 \\
\hline $18: 1 n-9$ & 32.8 & 32.4 & 23.8 & 51.6 & 19.0 \\
\hline $18: 1 n-7$ & 1.9 & 2.8 & 1.5 & 2.6 & 0.8 \\
\hline $18: 2 n-6$ & 25.0 & 22.9 & 50.0 & 22.8 & 14.3 \\
\hline $18: 3 n-3$ & 1.3 & 1.1 & 8.7 & 10.0 & 8.4 \\
\hline $20: 0$ & 0.2 & 0.2 & 0.4 & 0.8 & 0.8 \\
\hline $20: 1 n-9$ & 0.5 & 0.6 & 0.4 & 2.1 & 6.3 \\
\hline $22: 0$ & 0.1 & 0.1 & 0.4 & 0.5 & 0.7 \\
\hline $22: 1 n-9$ & 0.1 & 0.1 & 0 & 0.8 & 42.9 \\
\hline $24: 0$ & 0.2 & 0.1 & 0.1 & 0.2 & 0.3 \\
\hline $24: 1$ & 0.1 & 0.1 & 0 & 0.3 & 1.1 \\
\hline$n-6$ PUFA b & 1.6 & 1.7 & 0 & 0 & 0 \\
\hline$n-3$ PUFA $c$ & 0.7 & 0.7 & 0 & 0 & 0 \\
\hline
\end{tabular}

a Colostrum and milk were each collected from 3 sows, and the values were averaged. Per cent lipid on wet weight basis: colostrum $4.6 \pm 0.6 \%(X \pm S D)$ and milk $15.4 \pm 8.4 \%$; and on dry weight basis: colostrum $18.8 \pm 4.2 \%$ and milk $59.1 \pm 11.7 \%$; $^{b}$ the $n-6$ PUFA (polyunsaturated fatty acids) include $20: 3 n-6,20: 4 n-6,22: 4 n-6$, and $22: 5 n-6 ;{ }^{c}$ the $n-3$ PUFA include $20: 5 n-3 ; 22: 5 n-3$ and $22: 6 n-3$.

form/methanol, 2:1, vol/vol extract using a Soxhlet HT-M6 system, Tecator AB, Hoganas, Sweden), ash (AOAC, 1980) and nitrogen (using an automatic Kjeldahl instrument, Keltec 1030, Tecator AB, Hoganas, Sweden) determinations were carried out on freeze-dried carcass samples. Sow-reared piglets, matched by sex and live body weight to the artificially reared pigs, were processed similarly.

\section{Statistical analyses}

The artificially reared piglets came from 4 experiments, in which the piglets were killed at various ages between 7 and $16 \mathrm{~d}$. Therefore, for each artificial diet, the carcass differences between piglets receiving that diet and their sow-reared controls (matched by body weight and sex) were assessed separately, using a paired $t$-test (Snedecor and Cochran, 1967). Because of possible effects due to differences in age be- tween the artificially reared piglets and their sow-reared controls, the data were reanalyzed with age as a covariate.

\section{RESULTS}

The carcass per cent composition data presented in table III show significant differences between the artificially fed and sow-reared piglets in all comparisons except for the $\%$ ash data of the piglets eating the oil containing $2 \%$ erucic acid. Carcasses from piglets eating the milk replacer diet contained more \% nitrogen and $\%$ ash, and less $\%$ fat than the corresponding sow-reared animals.

The artificially and sow-reared groups were matched by live body weight and sex, but the sow-reared animals had more car- 


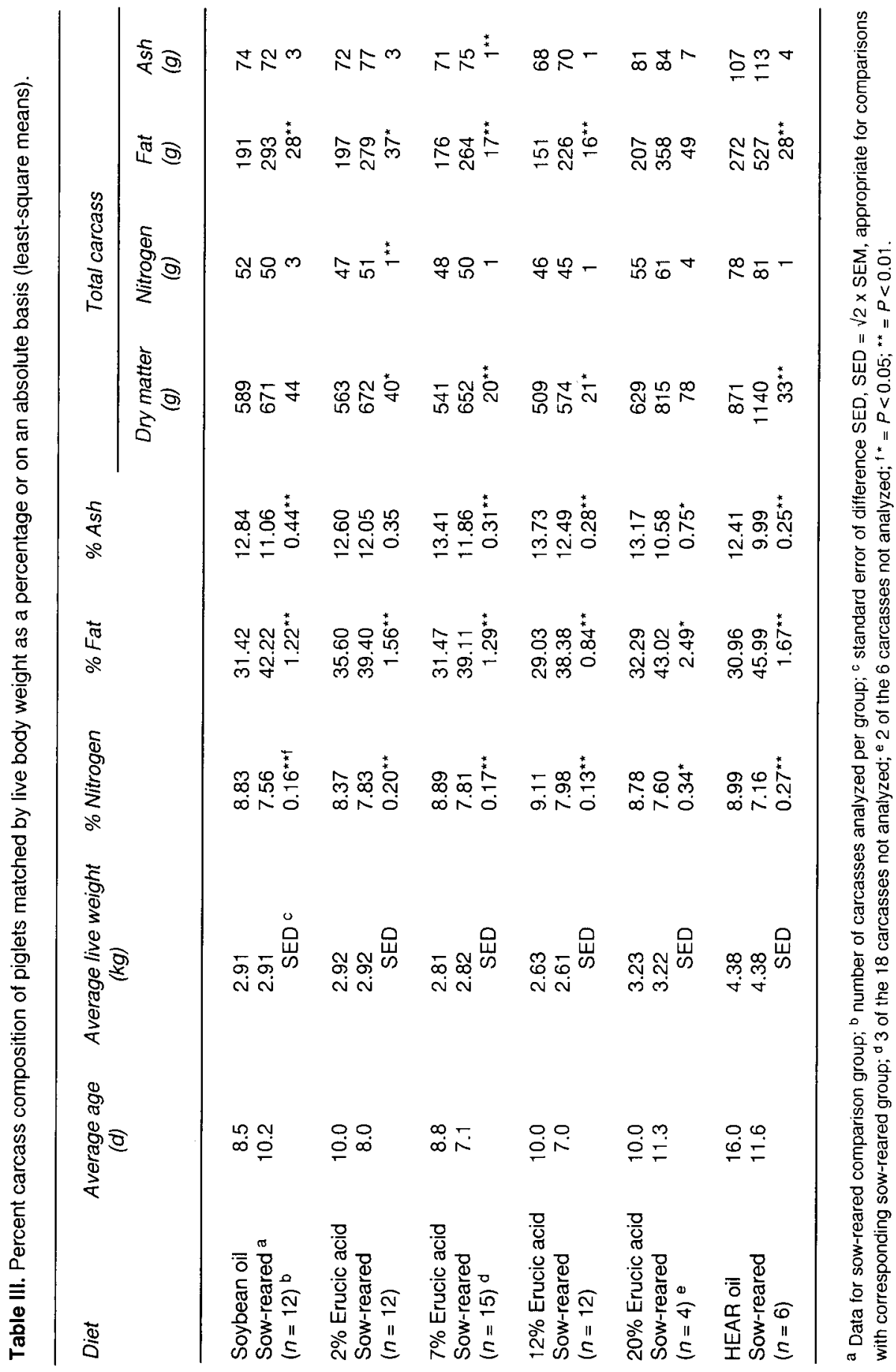


cass dry matter; in 4 of the 6 comparisons these differences were significant $(P<$ 0.05). The carcass composition data, expressed in absolute terms, indicate that these differences in total carcass dry matter were almost entirely accounted for by the differences in carcass fat; in 5 of the 6 comparisons, these differences were significant.

Sow-reared pigs were chosen on the basis of their live body weight and sex. As a result, there was no consistent pattern when the average age of the groups of piglets eating the milk replacer was compared to their sow-reared comparison groups (table III). To determine whether age at slaughter was affecting the results, the data were reanalyzed using age as a covariate. The adjusted least-square means were very similar to those shown in table III, and the trends outlined above were still evident. However, the significance level of the dietary trends was reduced primarily due to increased standard error of the differences (SED).
Table IV summarizes the lipid apparent digestibility data collected during the feeding trials. Feces were not passed regularly, and when they were, the amount was small. The apparent total lipid digestibility of all diets was greater than $90 \%$, with a tendency to decline with age. Although true comparisons among the diets were not possible, it appeared that the lipid in the milk replacer containing HEAR oil was slightly less digestible by 10-12 d (approximately $91 \%$ ) than the other vegetable oils. Both the dry matter and the nitrogen apparent digestibilities (data not presented) were very high (approximately 97\%) and showed no significant changes with age or dietary oil source.

The fatty-acid patterns of the oil blends used in the milk replacers differed from the fatty-acid pattern of sows' milk (table II). The sows' milk was high in palmitic acid $(23 \%, 16: 0)$, high in oleic acid $(32 \%$ $18: 1 n-9)$, and contained long-chain PUFAs of the $n-3(0.7 \%)$ and $n-6(1.7 \%)$ families. Linoleic acid $(18: 2 n-6)$ was in

Table IV. Total lipid apparent (\%) digestibility of milk replacer diets.

Diet

Days on diet a

\begin{tabular}{lllll}
\hline-3 & $4-6$ & $7-9$ & $10-12$ & $13-15$
\end{tabular}

$\begin{array}{llllll}\text { Soybean oil } & 99.2 \pm 0.4^{\mathrm{b}}(7)^{\mathrm{c}} & 99.9 \pm 0.0(5) & 99.4 \pm 0.1(3) & -\mathrm{d} & - \\ \text { 2\% Erucic acid } & 99.4 \pm 0.1(5) & 99.0 \pm 0.2(9) & 98.4 \pm 0.4(6) & 98.6(1) & - \\ 7 \% \text { Erucic acid } & 99.2 \pm 0.3(7) & 99.2 \pm 0.2(11) & 99.4 \pm 0.1(3) & 97.5 \pm 0.4(2) & - \\ 12 \% \text { Erucic acid } & 99.8 \pm 0.7(7) & 99.2 \pm 0.3(7) & 99.5(1) & 99.4 \pm 1.0(3) & - \\ 20 \% \text { Erucic acid } & 99.6 \pm 0.2(4) & 99.5 \pm 0.2(3) & 98.2 \pm 0.6(3) & 98.4(1) & - \\ \text { HEAR oil } & 98.5 \pm 1.1(3) & 95.7 \pm 1.2(6) & 90.9 \pm 2.5(6) & 91.4 \pm 1.0(6) & 93.8 \pm 1.2(6)\end{array}$

a Animals were $1 \mathrm{~d}$ old at the start of the experiment; ${ }^{b}$ means \pm standard error of mean; ${ }^{c}$ number of observations; ${ }^{d}$ no data available. 
high abundance $(22.9 \%)$, but linolenic acid was less $(1.1 \% 18: 3 n-3)$. The mixtures of canola and HEAR oil had graded $(0.8$ to $42.9 \%$ ) levels of erucic acid, high levels of $18: 3 n-3$, and, depending upon the mixture, high $18: 2 n-6$ and $18: 1 n-9$. Neither the canola/HEAR oil-based nor the soybean oil diets contained $\mathrm{C}_{20}$ and $\mathrm{C}_{22}$ PUFAs.

The major fatty acids found in the backfat of animals fed the different oils and the sow-reared piglets are compared in figure
1. The erucic acid levels in the backfat of the piglets eating milk replacers containing these oils reflected the diet patterns. In the animals receiving the $43 \%$ erucic diet, the backfat concentration was approximately $18 \%$; when the diet level was reduced to $2 \%$, erucic acid was still being laid down in the backfat $(0.6 \%$ of total fatty acids).

All the piglets receiving milk replacer had diets containing $15-25 \%$ linoleic acid (18:2 $n-6)$, except for the group receiving the soy diet (see fig 1). The linoleic acid

\section{2:1 n-9}

$18: 2 n-6$

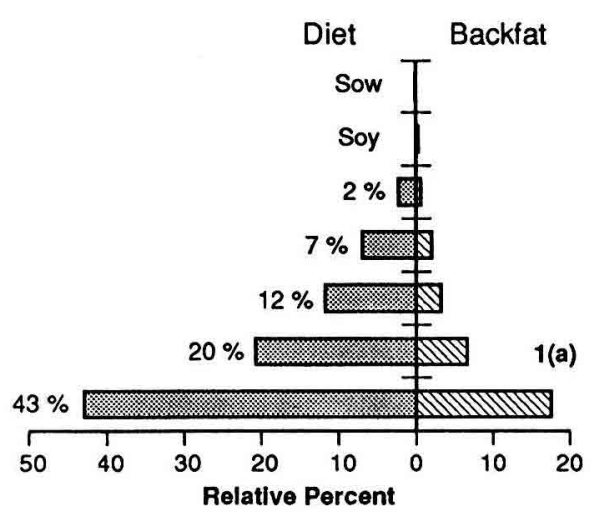

$18: 3 n-3$

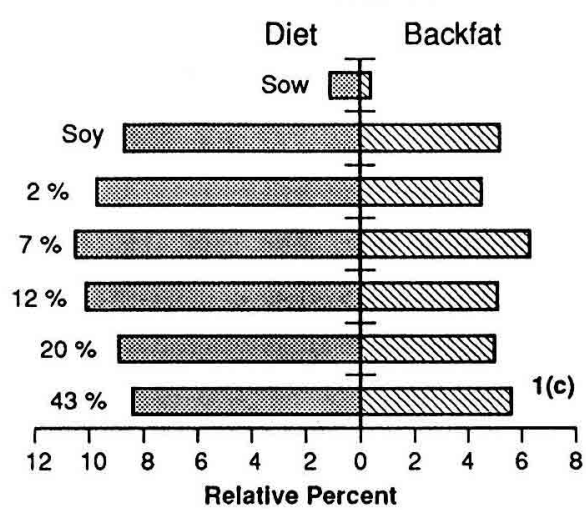

Soy

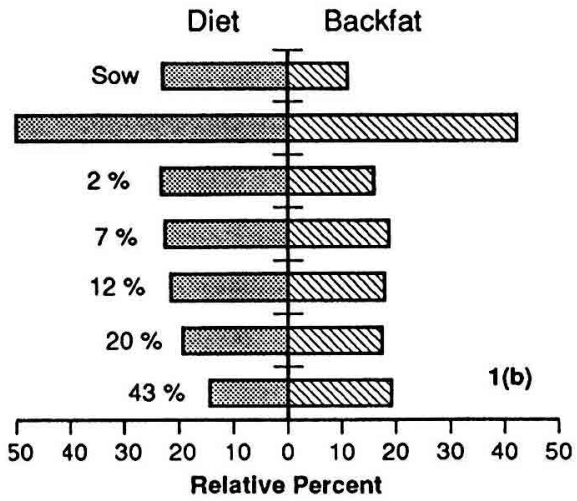

PUFA

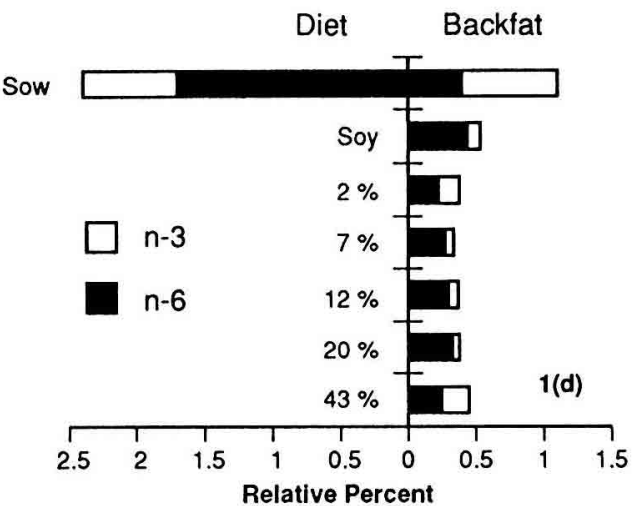

Fig 1. Fatty acid levels in diet and piglet backfat. All values are expressed as relative per cent of total fatty acids. Only certain fatty acids are presented: erucic acid (22:1n-q); linoleic acid (18:2 $n-6)$; linolenic acid (18:3n-3); and total $\mathrm{C}_{20}$ and $\mathrm{C}_{22}$ polyunsaturated fatty acids (PUFA). The PUFAs were separated into those derived from the $n-6$ and $n-3$ families. 
content in the backfat of these pigs ranged between 12\% (sow-reared) and 15-20\% (rapeseed oil diets). The backfat 18:2n-6 levels were more than doubled when soybean oil was the vegetable oil in the milk replacer. This was the same whether the data was calculated on a relative per cent basis (as in fig 1) or using the values in table III on a whole body basis (not shown).

The linolenic content of piglet backfat was very low $(0.3 \%)$ for piglets that received only sows' milk. Sows' milk is low in $18: 3 n-3$ relative to the vegetable oil tested. A greater than 10 -fold increase was found in backfat concentration of $18: 3 n-3$ by feeding soybean or rapeseed vegetable oils, compared to sow-reared piglets.

The concentrations of the $\mathrm{C}_{20}$ and $\mathrm{C}_{22}$ of the $n-6$ and $n-3$ PUFAs have been separately identified in figure 1 . Individual fatty acids were often present in trace amounts and, therefore, metabolically related fatty acids were summed. The $n-6$ data represent the sum of $20: 3 n-6$, $20: 4 n-6,22: 4 n-6 ;, 22: 5 n-6$; the $n-3$ data are the sum of $20: 5 n-3,22: 5 n-3$, $22: 6 n-3$. It is apparent that sows' milk was a good source (greater than $2.4 \%$ ) of these PUFAs, but the vegetable oils contained none. In spite of this, the backfat of all piglets had low but measurable levels of these $n-6$ (approx $0.3 \%$ ) and $n-3$ (approx $0.1 \%$ ) fatty acids. It is perhaps noteworthy that the animals eating the milk replacer containing soybean oil had the highest level $(0.44 \%)$ of $n-6$ PUFAs.

\section{DISCUSSION}

A proper nutritional evaluation of piglets eating milk replacer diets compared to sow-reared piglets is difficult, because of the differences in the way in which the piglets receive their milk. Piglets are generally fed the milk replacer based on their individual body weights, and therefore their growth is controlled. The amount of milk obtained by a sow-reared piglet depends on litter size, body weight of piglet relative to the others in the litter, health status, nutrition of the sow and other factors. Trying to match the intake of sows' milk to that received by the artificially reared pigs or vice versa is not possible. This is evident in previous reports where artificially reared piglets were sampled; Wolfe et al (1977) chose age as a criterion, while Campbell and Dunkin (1982) chose body weight. When the ages of the various artificially and sow-reared groups in our study were compared, in 2 cases, the sow-reared were on average older and, in 4 cases, the artificially reared were older. The composition of the carcasses change in relative and absolute terms as the animal ages, therefore, our data were reanalyzed using the ages of the pigs as covariates. Since there was little change in the least-square means, and the general trends and conclusions were the same, it would appear that sampling on either an age or a body weight basis is appropriate.

Sows' milk fatty acids typically contain $22-28 \% 16: 0,5-7 \% 18: 0,30-35 \% 18: 1 n-$ $9,15-25 \% 18: 2 n-6,1 \% 18: 3 n-3$ and $\mathrm{C}_{20}$ and $\mathrm{C}_{22} n-6(2 \%)$ and $n-3(1 \%) \mathrm{PU}-$ FAs (Hrboticky et al, 1989; Kramer et al, 1990). The fatty acid composition of sows' milk can be changed by feeding sows different fats during late gestation and lactation (Miller et al, 1971; Stahly et al, 1981). However, small amounts of $\mathrm{C}_{20}$ and $\mathrm{C}_{22}$ $n-6$ and $n-3$ PUFAs are always present in milk, presumably because they are essential for brain, retina and nervous system development in the neonate (Koletzko, 1992).

Vegetable oils do not contain any $\mathrm{C}_{20}$ or $\mathrm{C}_{22} n-6$ or $n-3$ PUFAs. In spite of this, we found small but measurable amounts of $\mathrm{C}_{20}$ or $\mathrm{C}_{22}$ PUFAs in the adipose tissue of 
piglets fed milk replacer. Hrboticky et al (1991) and Arbuckle et al (1992) reported even higher levels of $\mathrm{C}_{20}$ or $\mathrm{C}_{22}$ PUFAs in more metabolically active tissues, such as brain, liver and retina of piglets fed milk replacers containing vegetable oils. These PUFAs could only have arisen from desaturation-chain elongation by the piglet, or were transferred intact during gestation. We have reported the presence of these fatty acids in fetal tissues as well as in sow and fetal blood (Farnworth and Kramer, $1989 \mathrm{ab})$. However, given the growth of the adipose tissue post-birth and the concentrations of these fatty acids in the adipose tissue of milk replacer fed versus sowreared piglets, it would appear that some desaturation-elongation of $18: 2 n-6$ and $18: 3 n-3$ fatty acids is occurring in the milk replacer-fed piglets. If desaturationelongation were occurring, it would follow that the animals with the greatest supply of precursor fatty acids $(18: 2 n-6$ and $18: 3 n-3)$ would have the largest concentrations of the end products of synthesis $\left(\mathrm{C}_{20}\right.$ and $\left.\mathrm{C}_{22}\right)$. This is in fact what we found. The group eating soybean oil was receiving the largest amounts of 18:2n-6 and had the highest levels of $n-6$ PUFA's in their adipose tissues. This is consistent with the report of Arbuckle and Innis (1992) that showed when $18: 3 n-3(0.7 \%$ of total fatty acids) is the only source of $n-$ 3 fatty acids in a piglet milk replacer, tissue deposition of $22: 6 n-3$ is reduced but comparable to piglets receiving sows' milk. Obviously, both $18: 2 n-6$ and $18: 3 n-3$ are necessary components of a pig milk replacer, but there is not enough evidence at this time to set a requirement level for either.

HEAR oil and, in particular, erucic acid have been shown to be poorly digested and utilized by rats, rabbits and guinea pigs (Deuel et al, 1948; Carroll, 1957). In contrast, the digestibility of HEAR oil in the adult pig was shown to be $91 \%$ compared with $96 \%$ for soybean oil (Paloheimo and Jahkola, 1959). Our data indicate that oils high in erucic acid are highly digestible in the neonatal pig. The results for the digestibility and tissue deposition of erucic acid in the pig would appear to be very similar to the digestibility (Holmes, 1918) and accumulation of erucic acid (Shenolikar, 1980) in humans. In addition, erucic acid was deposited in the adipose tissue, like most fatty acids consumed by neonatal swine. This would mean that the pig is more like the human than the rat and can be used as a model to evaluate the nutritional and toxicological properties of oils containing erucic acid.

Sows' milk contains approximately $40 \%$ fat on a dry matter basis. Stable milk replacers used in this study were formulated with $25 \%$ fat by the addition of emulsifiers. Piglets receiving the milk replacer were limited in the total amount of feed that they received. It is apparent from our data (carcass fat data, table III) that, when the dietary fat intake of newborn piglets is restricted, not only does the total amount of fat stored in the carcass decrease, but the proportion of carcass fat also declines. In their feeding trial using diets containing different fat levels, Wolfe et al (1977) obtained similar results.

In sow-reared piglets the time between birth and weaning is one of rapid fat accretion (Farnworth and Kramer, 1987) when adipocytes increase in size and lipid content (Moody et al, 1978). By using an artificial rearing system using milk replacer, in which the level and type of fat can be controlled, feeding regimes may be developed that optimize desired growth or compositional characteristics.

\section{ACKNOWLEDGMENT}

The assistance of the swine staft is acknowledged. R Cooligan helped prepare the milk re- 
placer; $\mathrm{S}$ Winter carried out the carcass analyses. All animal experiments were reviewed to ensure adherence to Canadian Council on Animal Care (CCAC) guidelines. Centre for Food and Animal Research Contribution No 1755; Research Program Services Contribution No R 088.

\section{REFERENCES}

Arbuckle LD, Innis SM (1992) Docosahexaenoic acid in developing brain and retina of piglets fed high or low $\alpha$-linolenate formula with and without fish oil. Lipids 27, 89-93

Arbuckle LD, Rioux FM, Mackinnon MJ, Innis SM (1992) Formula $\alpha$-linolenic (18:3(n-3)) and linoleic (18:2(n-6)) acid influence neonatal piglet liver and brain saturated fatty acids, as well as docosahexaenoic acid $(22: 6(n-3))$. Biochim Biophys Acta 1125, 262-267

AOAC (Association of Official Analytical Chemists) (1980) Official Methods of Analysis, 13th ed $A O A C$, Washington, DC

Campbell RG, Dunkin AC (1982) The effects of birth weight and level of feeding in early life on growth and development of muscle and adipose tissue in the young pig. Anim Prod 35, 185-192

Carroll KK (1957) Rape oil and cholesterol metabolism in different species with reference to experimental atherosclerosis. Proc Soc Exp Biol Med 94, 202-205

Christie WW (1982) Lipid Analysis, 2nd Edition, Pergamon Press, Oxford, pp 19-20

Deuel HJ, Cheng ALS, Morehouse MG (1948) The digestibility of rape-seed oil in the rat. $J$ Nutr 35, 295-300

Elliot JI, Lodge GA, Hartsock TG (1978) Practical artificial rearing of neonatal piglets under non-isolation conditions. Can J Anim Sci 58, 799-800

Elliot Jl, Modler HW, Timbers GE (1987) A continuous process from the production of purified porcine rglobulin for use in pig milk replacer supplements. Anim Feed Sci Technol 17, 213-218

Farnworth ER, Kramer JKG (1987) Fat metabolism in growing swine: a review. Can $J$ Anim Sci 67, 301-318
Farnworth ER, Kramer JKG (1989a) Changes in the lipid composition of the internal organs of fetal pigs from sows fed different dietary fats. Can J Anim Sci 69, 441-448

Farnworth ER, Kramer JKG (1989b) The effects of changing sow dietary fatty acids on fetal plasma fatty acid patterns. Can J Anim Sci 69, 813-817

Farnworth ER, Dilawri N, Yamazaki $H$, Modler HW, Jones JD (1990) Studies on the effect of adding Jerusalem artichoke powder to pig milk replacer. Can J Anim Sci71, 531-536

Holmes AD (1918) Digestibility of some seed oils. US Dept Agric Bull 687

Hrboticky N, Mackinnon MJ, Innis SM (1991) Retina fatty acid composition of piglets fed from birth with a linoleic acid-rich vegetable-oil formula for infants. Am J Clin Nutr 53, 483-490

Hrboticky N, Mackinnon MJ, Puterman ML, Innis SM (1989) Effect of linoleic acid-rich infant formula feeding on brain synaptosomal lipid accretion and enzyme thermotropic behaviour in the piglet. $J$ Lipid Res 30, 1173-1184

Koletzko B (1992) Fats for brains. Eur J Clin Nutr 46 (suppl 1), S51-S62

Kramer JKG, Farnworth ER, Thompson BK (1985) Quantitating heart lipids: comparison of results obtained using the latroscan method with those from phosphorus and gas chromatographic techniques. Lipids 20, 536-541

Kramer JKG, Farnworth ER, Johnston KM, Wolynetz MS, Modler HW, Sauer FD (1990) Myocardial changes in newborn piglets fed sow milk or milk replacer diets containing different levels of erucic acid. Lipids 25, 729-737

Lecce JG (1975) Rearing piglets artificially in a farm environment: a promise unfulfilled. $J$ Anim Sci 41, 659-666

Lecce JG (1986) Diarrhea: the nemesis of the artificially reared, early weaned piglet and strategy for defense. J Anim Sci 63, 1307-1313

Miller GM, Conrad JH, Harrington RB (1971) Effect of dietary unsaturated fatty acids and stage of lactation on milk composition and adipose tissue in swine. J Anim Sci 32, 79-83

Moody WG, Enser MB, Wood JD, Restall DJ, Lister D (1978) Comparison of fat and muscle development in pietrain and Large White piglets. J Anim Sci 46, 618-633

Paloheimo L, Jahkola B (1959) Digestibility of soybean oil and rape oil by swine. J Sci Agric Soc Fin/ 31, 212-214 
Patience JF, Farnworth ER (1989) Preparation of neonatal carcass homogenates by autoclaving: influence on proximate and lipid analysis. Can J Anim Sci 69, 34†-346

Reid WS, Buckley DJ, Elliot JI, Nicholls CF (1979) A six-cage automatic feeding system for neonatal pigs. Can J Anim Sci 59, 619-622

Sauer FD, Kramer JKG (1983) The problem associated with the feeding of high erucic acid rapeseed oils and some fish oils to experimental animals. In: High and Low Erucic Acid Rapeseed Oils (JKG Kramer, FD Sauer, WJ Pigden, eds) Academic Press, New York
Shenolikar I (1980) Fatty acid profile of myocardial lipid in populations consuming different dietary fats. Lipids 15, 980-982

Snedecor GW, Cochran WG (1967) Statistical Methods, Sixth Edition. lowa State University Press. Ames, lowa, p 94-95

Stahly TS, Cromwell GL, Simpson WS (1981) Effects of level and source of supplemental fat in the lactation diet of sows on the performance of pigs from birth to market weight. $J$ Anim Sci 51, 352-360

Wolfe RG, Maxwell CV, Nelson EC, Johnson RR (1977) Effect of dietary fat level on growth and lipogenesis in the colostrumdeprived neonatal pig. J Nutr 107, 2100-2108 